\title{
TO THE QUESTION OF THE CLUSTER APPROACH IN TOURISM OF KAZAKHSTAN
}

\author{
Rysty Karuevna Sadykova, ${ }^{1}$ Assem Madysheva ${ }^{2}$
}

\begin{abstract}
In recent years, the cluster approach has become the main instrument of an effective state strategy for the development and management of tourism in countries with a high level of competitiveness. It is based on the interaction and cooperation of organizations operating in the tourism industry and government structures, without which innovation activity cannot be managed, new approaches emerge that involve an indirect impact on the development of the region within the national innovation system by creating conditions for increasing innovation activity and susceptibility of economic entities. The development of many regions is constrained by the lack of necessary conditions: inadequate material and financial resources, underdeveloped research base, inconsistent regional policies.
\end{abstract}

JEL Classification Number: Z32; DOI: http://dx.doi.org/10.12955/cbup.v5.959

Keywords: Competitiveness, tourism, tourist product, clustering of tourist activity, infrastructure.

\section{Introduction}

Tourism in modern society is one of the most important aggregated branches of the state economy, involving in its orbit a whole set of directions - both at the level of direct contact with the traveller (transport, tourist firms, accommodation and food systems, cultural and entertainment, sports and health, sanatorium- Resort complexes, etc.), and indirectly involved in the formation of a comprehensive tourist service (agriculture, processing industry, fuel and energy complexes, the automotive industry and the production of other means of transportation, communications, the construction complex, souvenir industry, and others).

In the tourist industry, there are various tourist organizations. Balabanov et al. (2001) stated that some of them provide clients with exclusively tourist services, while for others, tourism is one of several areas of their commercial activities. Organizations that exist only at the expense of tourism are called tourist organizations of primary services, and organizations that receive incomes not only from tourism activities are tourism organizations in the sphere of secondary services.

In this paper, the following methods were used:

- monographic (when collecting data from primary documents available in the presence of tourist infrastructure);

- grouping method (when grouping enterprises by homogeneous characteristics);

- settlement-constructive (when calculating indicators for medium- and long-term prospects);

- economic and mathematical methods (in the formation of models and variants of tourist clusters).

\section{Role of tourism in the socio-economic system of the region}

As Bogolyubov et al. (2005) stated, traditionally, the development and sale of tourism products are engaged in two types of tourist organizations that are part of the tourist industry: tour operators and travel agents.

Tour operator (in the international practice, sometimes the term "tour operator" is used) is an organization engaged in bundling of tours under contracts with service providers and in accordance with the needs of tourists. The tour operator develops tourist routes, provides them with services, organizes advertising, calculates and sets prices for tours on these routes, sells tours to a travel agent for the issue and sale of vouchers. The tour operator is responsible for providing the services included in the tour package. Sometimes he provides these services himself, receiving them from a counterparty or being the owner of hotels, restaurants, etc.

Most often, tours are compiled by a tour operator for a wholesale agency that offers these packages under its own name through its retail agents or through airlines.

According to Azrilian (1997) a travel agent is an organization that purchases tours developed by a tour operator, issuing permits for these tours and selling them to the consumer.

\footnotetext{
${ }^{1}$ Kazakh National University of Economics, Finance and International Trade, Astana, Kazakhstan, rystysadykova@mail.ru

${ }^{2}$ Kazakh National University of Economics, Finance and International Trade, Astana, Kazakhstan,

asem_madysheva@mail.ru
} 
According to Gulyaev (1996) travel agents perform two main functions:

1. provision of information services (report on tourist areas, accommodation options, help to make an estimate of the cost of travel);

2. marketing of tourist services.

In this regard, we can conclude that the organization of the tourism industry is divided into three groups:

- tourist organizations in the sphere of primary services;

- tourist organizations in the sphere of secondary services;

- tourist organizations (travel companies, travel agents, travel agencies), which act as a link between the tourist-consumers of services and the tourism industry itself, which offers services. This group includes organizations of transport and communications that carry tourists to a place where they will be given hospitality, moreover, transportation costs and services of tour operators are included in the cost of the voucher.

In the statistics of the country there is no criterion for identifying the sphere of activity occupied by the hospitality industry. It is very difficult to single out the tourism industry as a separate industry and to consider it outside of the connection with other objects of the tourism industry. Certainly, sanatoriums and boarding houses belong to the sanatorium and resort sector, restaurants and cafes to public catering, but if they are concentrated within one tourist-recreational, sports-recreational or culturalentertainment complex, this is the tourism industry.

The services of the tourism industry are of a complex nature and thus, cause demand for a number of other goods and services. Therefore, for a more correct understanding of the structure of the hospitality industry, taking into account the existing motivations for consumers of tourism services, as well as analysis of current trends in world and Kazakhstan tourist flows, the services of the hospitality industry should be classified as shown in Figure 1.

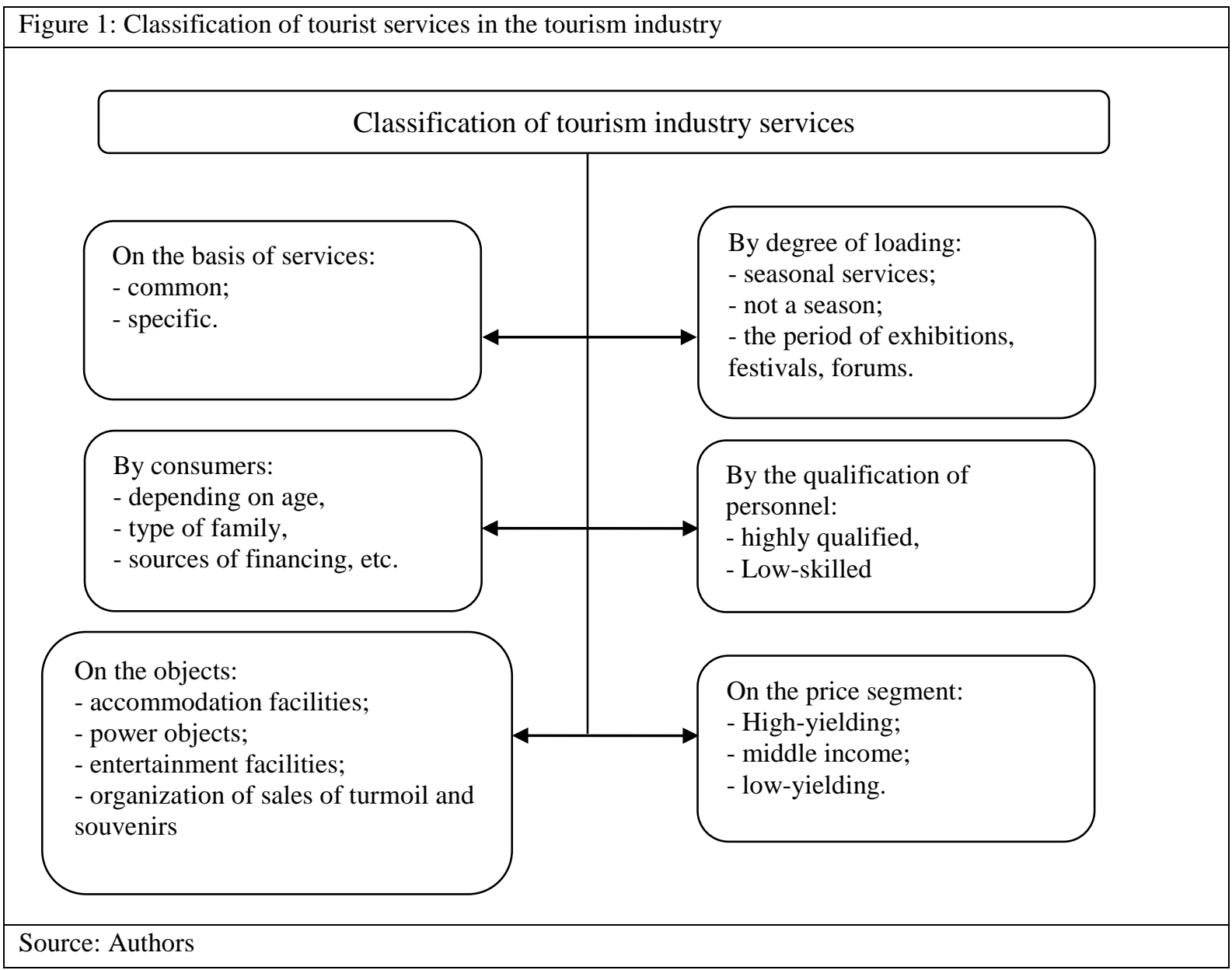


At present, it is difficult to single out the tourism industry as a separate industry. If about twenty years ago there were clear spheres: hotel industry, sanatorium and health resort, catering, leisure, now there is a mass of tourist-recreational, sports and recreational, cultural and entertainment complexes that unite these spheres into a single whole. Particularly there are difficulties with the placement sector. Institutionally, tourism is a branch of the national economy (Figure 2).

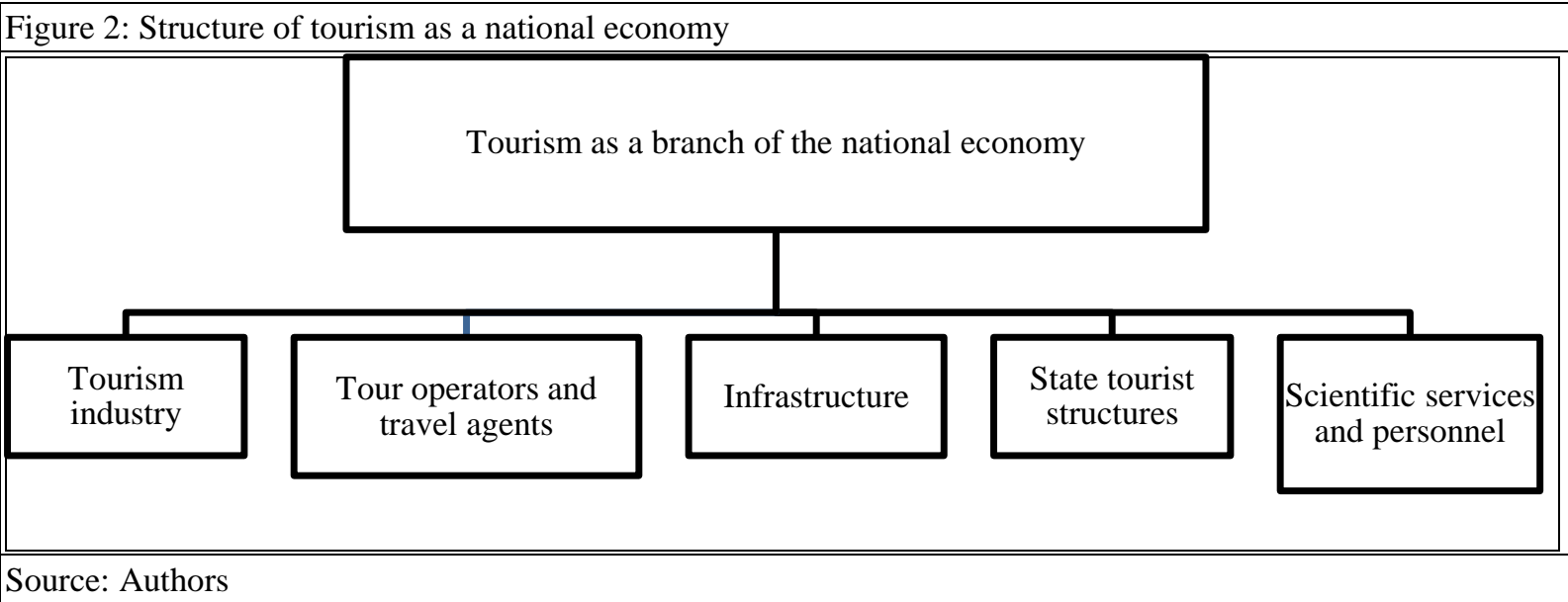

\section{Scientific approaches to the definition of cluster and cluster development of tourism}

According to Pyatinkin et al. (2014) clusters are a community of organizations from closely related industries, mutually contributing to the growth of each other's competitiveness, playing the role of "locomotives" 3 for the development of industries.

Raisberg et al (2005) found that beginning from the 1990s, clusters around the world began to play a major role in the formation of innovative development strategies related to the orientation to local competitive advantages of socio-economic, scientific and production systems, which led to a revision of the foundations of economic and technological policies, and dominated earlier models of centralized development.

As Medynskiy (2007) stated for the first time the concept of "cluster" was introduced into scientific circulation by the American economist M. Porter, who defined the cluster as a group of geographically neighboring interconnected companies and related organizations operating in a certain sphere, characterized by common activities and mutually complementary

Sozieva (2009) found that the experience of many countries shows that clusters really contribute to the high efficiency of the economy and, thus, improve the welfare of the nation. In the world practice, a great deal of experience has been accumulated in the development of clusters, studies are conducted on a whole range of directions (Table 1). A special role for foreign scientists is given to the development and stimulation of cluster initiatives, as well as the formation of a policy to support clusters.

By definition of Ivanenko (2008) a cluster is a group of geographically integrated interconnected enterprises, equipment suppliers and their components, specialized services, infrastructure, research institutes and universities and related organizations operating in a particular industry, combined and complementary to each other Friend, enhancing the competitive advantages of individual companies and the cluster as a whole.

The cluster approach used in the studies of competitiveness, over time, has been used to solve an increasingly wide range of problems: in analysing the competitiveness of the state, region, and industry; as the basis of a nation-wide industrial policy; when developing regional development programs; as a basis for interaction between big and small businesses.

Kazakhstan's economic science in this area is based on the borrowing of foreign experience. Thus, the domestic economists Baymuratov (2005) stated, on the basis of studying the European experience, that

${ }^{3}$ Locomotive - driving force 
the cluster is defined as a network of suppliers, producers, consumers, elements of industrial infrastructure, research institutes interconnected in the process of creating added value.

\begin{tabular}{|c|c|}
\hline Directions & Results \\
\hline $\begin{array}{l}\text { 1. The role of entrepreneurship in the formation } \\
\text { and increase of activity of clusters }\end{array}$ & $\begin{array}{l}\text { Expansion of entrepreneurial activity contributes to } \\
\text { the accelerated formation of clusters, which, in turn, } \\
\text { ensure the effectiveness of the entrepreneurial } \\
\text { subsystem }\end{array}$ \\
\hline $\begin{array}{l}2 . \quad \text { Influence of clusters and tourist } \\
\text { configurations on the growth of } \\
\text { entrepreneurship at the regional level }\end{array}$ & $\begin{array}{l}\text { In the regional aspect, tourist configurations form a } \\
\text { certain type of clusters, contributing to the growth of } \\
\text { entrepreneurial activity }\end{array}$ \\
\hline $\begin{array}{l}\text { 3. Local dynamics and global links - the role } \\
\text { of inter-organizational ties within the cluster } \\
\text { and global value chains in stimulating } \\
\text { innovation and entrepreneurship }\end{array}$ & $\begin{array}{l}\text { The study of local dynamics and global economic ties } \\
\text { proves the effectiveness of clustering IDs in } \\
\text { improving the innovativeness of regions }\end{array}$ \\
\hline $\begin{array}{l}\text { 4. Importance of territorial proximity between } \\
\text { business activities and sources of knowledge }\end{array}$ & $\begin{array}{l}\text { Territorial proximity continues to remain a priority in } \\
\text { the formation of clusters }\end{array}$ \\
\hline $\begin{array}{l}\text { 5. Relations between knowledge bases at the } \\
\text { level of organizations, cluster capabilities and } \\
\text { the potential for economic growth of clusters }\end{array}$ & $\begin{array}{l}\text { Clustering provides a level-by-level link between } \\
\text { subjects of microeconomics (firm), macroeconomics } \\
\text { (state), mega-economics (international institutions) }\end{array}$ \\
\hline $\begin{array}{l}\text { 6. The influence of the place of } \\
\text { entrepreneurial activity in providing regions } \\
\text { with qualified personnel due to the } \\
\text { development of educational infrastructure in } \\
\text { the regions }\end{array}$ & $\begin{array}{l}\text { The positive role of entrepreneurship as a source of } \\
\text { financing of the educational sphere is conditioned }\end{array}$ \\
\hline $\begin{array}{l}\text { 7. Alternative models for the formation and } \\
\text { development of cluster organization of } \\
\text { entrepreneurship in different regions }\end{array}$ & $\begin{array}{l}\text { Accounting for regional natural, climatic, } \\
\text { technological and production specifics determine the } \\
\text { differentiation in the typology of clusters }\end{array}$ \\
\hline $\begin{array}{l}\text { 8. Development of competitiveness of cross- } \\
\text { border clusters }\end{array}$ & $\begin{array}{l}\text { The most promising form of the cluster organization } \\
\text { is the transboundary cluster, which extends the } \\
\text { production, educational, scientific, innovative } \\
\text { potential of the territories }\end{array}$ \\
\hline
\end{tabular}

Another group of domestic economists Suraganova (2006), Ketels (2005), Nazarov (2005) cites the following definitions of the concept of cluster:

1. Regionally limited forms of economic activity within related sectors (technological affinity, for example, a biotechnological cluster), usually tied to one or another institution in the knowledge industry (research institutes, universities, etc.).

2. Vertical production chains: rather narrowly defined sectors, in which adjacent stages of the production process form the core of the cluster (for example, the chain "supplier - collector - marketer - client").

Namazbekov (2005) defines a cluster as high-tech industries defined at a high level of aggregation (for example, a "chemical cluster") or a set of sectors at an even higher level of aggregation (for example, an "agro-industrial cluster").

Within the framework of this research, the theoretical aspects of the cluster approach in the tourism industry were summarized, systematized and refined, namely: the definition of the concept of a "tourist cluster" was defined, the object, subjects, the purpose of the functioning of tourist clusters were determined, and the subjects of interaction of the target groups of tourist clusters were identified.

\section{The results of an empirical assessment of the relevance of the cluster approach to tourism regulation}

The purpose of this research is to study the prospects of creating a tourism cluster and the necessary forms of state support in the North-Kazakhstan region. The subjects of the analysis are:

- trends in the development of small businesses in the tourism (in terms of the main segments: health, cognitive, congress (business), sports, entertainment, religious tourism, etc.); 
- the needs of small business entities that carry out activities in the field of tourism, in state support (in accordance with the main forms of state support);

- problems that hamper the formation of the cluster and the development of small business in the tourism industry and recommendations on the mechanisms for their solution;

- prospects for the development of small business in the sphere of tourism;

- factors contributing to the formation of a cluster in the region.

Within the framework of the research of development trends, the following issues were studied: the financial situation of small business entities working in the sphere of tourism, the main segments of entry and domestic tourism in which they operate, the most attractive regions for tourism development and the places of the region, the development of certain types of tourism, and others.

When conducting an analysis of the needs of entrepreneurs in government support, measures of support for small business entities were considered. Currently, the state program "Road map of business 2020" is operating in the region.

The entrepreneur has the opportunity to receive on a free basis:

1. Support for start-ups (start-up projects), which includes:

a. short-term training of entrepreneurs and the public on the basics of entrepreneurial activity (the "Business Advisor" project);

b. provision of a standard package of documents necessary for the entrepreneur;

c. information and analytical support and organization of free access of entrepreneurs to a single enterprise base;

d. providing marketing research results in priority sectors of the economy.

2. Service support for running an existing business. This is aimed at improving the enterprise management system in order to improve its efficiency and includes the provision of the following specialized services to support business processes:
a. maintenance of accounting and tax accounting and reporting;
b. compilation of statistical reports;
c. customs procedures;
d. advising on the implementation of quality management systems;
e. lawyer consulting;
f. consulting on marketing issues;
g. service in the field of information technology.

In addition, the attitude of entrepreneurs to measures for the development of tourism in the area, which does not directly relate to supporting small business, was explored.

On the basis of the study, recommendations were made for creating a favorable climate for the formation and development of a cluster in the tourism sector in the North Kazakhstan region. In accordance with the Law of the Republic of Kazakhstan No. 211-II from June 13, 2001 "On Tourist Activities in the Republic of Kazakhstan", "inbound tourism" means travel within the Republic of Kazakhstan to persons who do not reside permanently in its territory and, "domestic tourism - travel within Of the Republic of Kazakhstan of citizens of the Republic of Kazakhstan and persons permanently residing in its territory. Within the framework of this study, segments of inbound and domestic tourism were studied, which for the purposes of the study were understood as travel of tourists to the North Kazakhstan region.

Empirical research base

The empirical basis for the study was an oral survey and a survey conducted in July-October 2015 and January 2016. Both studies were conducted in a comparable manner.

General population

The total population of the study is the participants in the tourism cluster. The participants of the tourism cluster are considered by us as a homogeneous aggregate, represented by a single sign "factors affecting the development of the tourism cluster in the North Kazakhstan region."

Selective aggregate

The study used a systematic probabilistic sample. Out of 80 enterprises, a route (a uniformly stretched chain of interviewers) selected 37 enterprises for interviewing. With a homogeneous population, a 
probabilistic systematic sample gave an equal opportunity for each participant in the cluster to become a respondent. The sampling error was 1.1 points with a probability of $95 \%$.

Method of collecting information

The following methods of information collection were used:

1. Formalized interview on the questionnaire (see below) 37 enterprises of participants in the tourism cluster of the North-Kazakhstan region.

2. Included monitoring of the group of experts in the process of seminars, conferences. Information was collected on the factors that affect the development of the tourism cluster, the assessment of the business environment of the tourist cluster by the criteria of M. Porter's model

Research toolkit

A questionnaire containing closed questions was used. In the sample, during the survey of small enterprises operating in the sphere of tourism, 37 enterprises from all regions of the North-Kazakhstan oblast were involved. Practically all respondents of the survey are organized in the form of limited partnerships (33 enterprises), two respondents are individual entrepreneurs.

The youngest enterprise among those who were in the sample was registered in 2015, the oldest in 1996. At the same time, the average age was 5 years.

The maximum number of employees of enterprises from the number of respondents in 2015 was 12 people, the minimum - 3. The average number of employees in 2015 was 6 people. Over the past 4 years, the number of employees of the small business subjects surveyed has changed insignificantly, in rare cases, in the direction of its increase.

Tourist activities are carried out by the overwhelming majority of their surveyed entrepreneurs - 25 respondents, tour operators - 5 enterprises and 5 enterprises combine these two activities.

In this subsection, an analysis is made of the development trends of small business entities that carry out their activities in the field of tourism, including their financial and economic situation, specialization in certain types of tourism, the most attractive regions and places in the tourist area.

The financial and economic situation of the enterprises surveyed is currently at a stable level. Thus, $47 \%$ of respondents rated it as good, $50 \%$ as satisfactory and $2 \%$ as very good. At the same time, it is possible to talk about the insignificant annual turnover of enterprises: the turnover of 6 enterprises surveyed in 2015 fell into the group to 500 thousand tenges, 11 - to the group from 500 thousand to 1 million tenges, and 5 - to the group from 1 million tenges Up to 2.5 million tenge. At the same time over the past 2 years only one of the small business subjects interviewed has made quite large investments.

As targets for the near future, more than half (51\% of respondents) plan to "slowly but develop," $30 \%$ set the task to develop at a fast pace, $5 \%$ - to keep the volumes. One respondent proposes to close the business.

Within the framework of a survey of small business entities operating in the tourism sector, problems characteristic of all small businesses were investigated, and factors that hampered the formation of the cluster and the development of domestic and incoming tourism in the region were identified.

Based on the results of the survey, it can be stated that respondents estimate the impact of problems typical for all small businesses on their activities as small.

Among the factors hampering the formation of the cluster and the development of domestic and inbound tourism (it was suggested to choose 3 options for the answer), the surveyed enterprises noted:

- Lack of sufficient tourist resources (16 respondents);

- insufficient level of development of the tourist and recreational infrastructure of the region (13 respondents);

- lack of well-developed tourist products (11 respondents);

- insufficient level of development of the service sector (6 respondents).

An important area of research is the assessment of the prospects for the development of a tourism cluster in the North Kazakhstan region by small business entities that carry out their activities in the tourism sector. Figure 3 shows the regions of the North-Kazakhstan region with the largest tourist potential. 


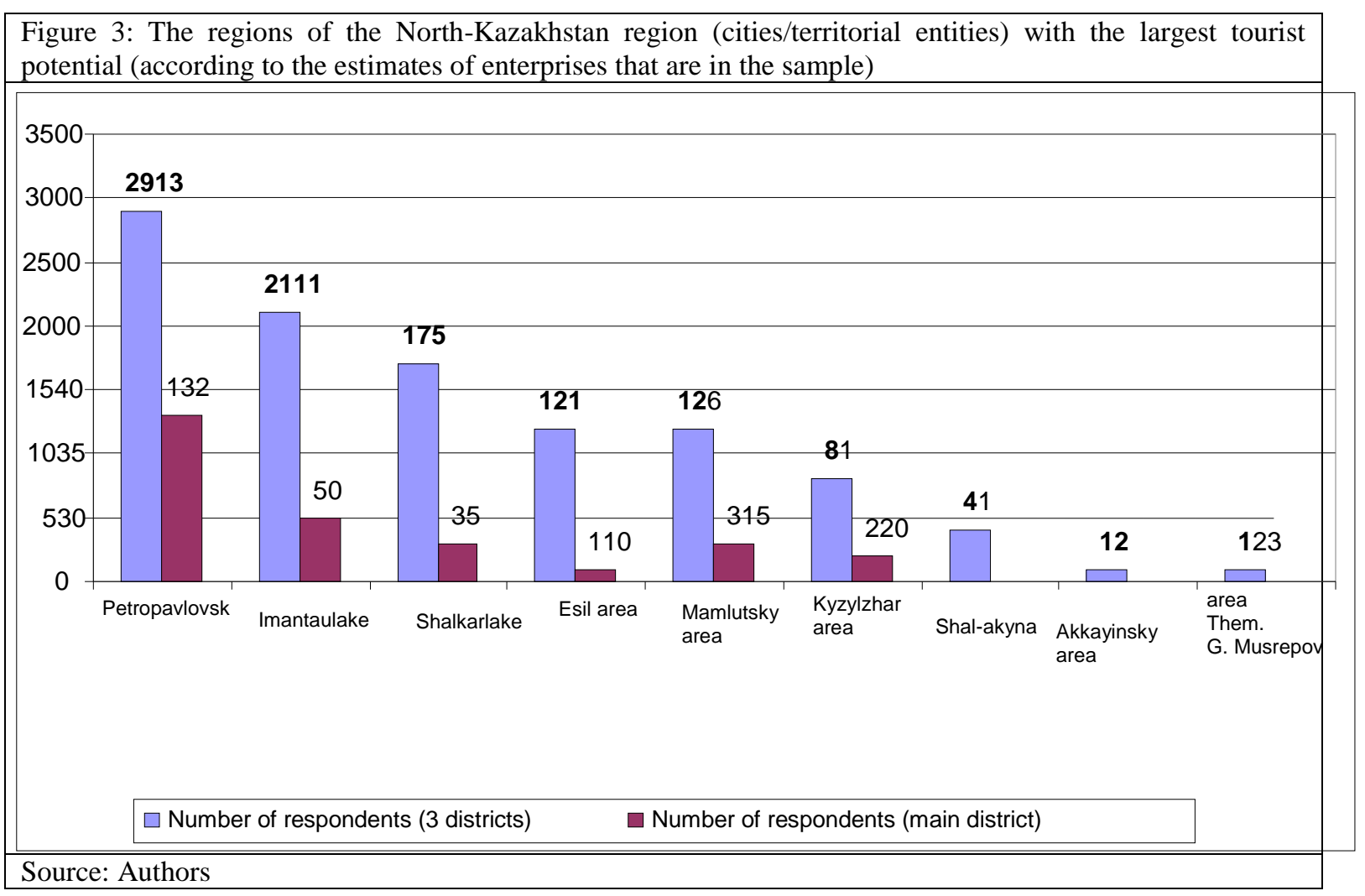

\section{Main findings:}

First, the reduction in the impact of factors that impede the formation and development of a cluster of tourism in the region should be conducted out by carrying out complex measures by the regional authorities. It should be noted that to level out such a factor as the lack of a sufficient number of tourist resources, it seems almost impossible, since it is conditioned by the inherent features of the territory (natural, historical, sociocultural and others).

Second, the analysis of the dynamics and trends in tourism development carried out in the work showed that, given the significant tourist and recreational resources in the North Kazakhstan region, there are all prerequisites for the competitive development of tourism and recreation and the consistent formation of a tourist and recreational cluster in the region.

Third, in order to attract foreign tourists to Kazakhstan, it is necessary that tourist products of Kazakhstan be included in the catalog of foreign tour operators and these tour packages should be installed at a low price to attract the largest number of tourists.

Fourth, the cluster functions only in a certain environment, namely under favorable conditions (political, socio-cultural, economic, natural), which are a combination of external factors that ensure the competitiveness of tourist services.

Fifth, to ensure the formation of favorable conditions for the development of clusters, it is necessary:

1. Enhancing the system of professional and continuing education.

2. Creation of industrial parks and industrial parks as an infrastructure for the development of clusters.

3. Implementation of targeted investments in the development of engineering and transport infrastructure, housing construction, which is implemented in view of the tasks of cluster development.

4. Implementation of tax regulation measures for cluster members.

5. Reducing administrative barriers.

\section{Conclusion}

Today, Kazakhstan can be viewed as a new emerging market for the development of cluster tourism with its biological and geological diversity, minimal population density, rich historical and cultural 
heritage. The state program will create a modern highly efficient and competitive tourism industry in the republic and ensure the development of related sectors of the economy.

The development of the economy made it possible to identify the specific features of the cluster approach, which consist in the formation of innovative clusters in three directions: developing policies to support the formation of clusters and creating an environment conducive to their effective functioning; determination of the main ways of development on the basis of an analysis of their potential, market needs and the overall external environment; development of its strategy, identifying and justifying the need and profitability for themselves in the creation and development of the cluster. At the same time, the competitiveness of each organization is linked to the performance of others involved in the value chain with supplier-buyer relations, local and regional institutions, resulting in a general increase in the competitiveness of the interconnected organizations (cluster) and, consequently, the region as a whole.

\section{References}

Balabanov, I.T., \&Balabanov A.I.(2001). Ekonomika turizma [Tourism Economics].Moscow: Finance and Statistics, 176.

Bogolyubov, V., \&Orlovskaya, V.P. (2005). Ekonomika turizma[Tourism Economics: Academy]. Moscow: Academia, 192.

Gulyaev, V. (1996). Organizatsiya turistskoy deyatel'nosti [Organization of tourist activity]. Moscow: Nolidzh, 312.

Pyatinkin, S.F., \&Bykova, T.P. (2014). Razvitiye klasterov: sushchnost', aktual'nyye podkhody, zarubezhnyy opyt [Development of clusters: essence, actual approaches, foreign experience]. Minsk: Tesei, 72.

Raisberg, B.A, \&Lozovskiy, L.Sh. (2005). Ekonomika I upravleniye [Economics and Management]. Moscow: Moscow Psychological and Social Institute, 248.

Medynskiy, V.G. (2007). Innovatsionnyy menedzhment [Innovative management]. Moscow:INFRA-M, 294.

Sozieva, Z.I. (2009). Formirovaniye i razvitiye turistsko-rekreatsionnykh klasterov (zarubezhnyy opyt) [Formation and development of tourist-recreational clusters (foreign experience)]. Regional Economy: Theory and Practice (25).

Ivanenko, L.V. (2008). Upravleniye regionom. Kontseptsiya mezhklasternoyo rganizatsii ekonomiki [Management of the region. The concept of intercluster organization of the economy]. Samara: SamNTS RAN, 212.

Aldashov, B. (2005). «Klasternost'» - dominiruyushchiy printsip regional'noy ekonomicheskoy politiki ["Clustering" is the dominant principle of regional economic politics]. Industry of Kazakhstan (6), 16-18.

Suraganova, S.K. (2006). Innovatsii v sotsio kul'turnom biznese i turizme [Innovations in the sociocultural business and tourism]. Astana, 23.

Ketels, K. (2005). Klasternoye razvitiye - vybor pobediteley ili vseobshcheye konkurentnoye ravenstvo? [Cluster development - the choice of winners or universal competitive equality?]. Industry of Kazakhstan (6), 14-15.

Nazarov, K. (2005). Klasternaya initsiativa v Kazakhstane [Cluster Initiative in Kazakhstan]. Stocks and bods market (7), 1315.

Namazbekov, M. (2005). Klasternoye razvitiye v usloviyakh globalizatsii: opyt zarubezhnykh stran [Cluster development in the context of globalization: the experience of foreign countries]. Analytic(3), 8-14.

Azrilian, A.N. (1997). Bol'shoy ekonomicheskiy slovar' [The Big Economic Dictionary]. Moscow: Institute of New Economy, 675.

Baymuratov, U. (2005). Gosudarstvennyye finansovyye instituty razvitiya v reshenii voprosov industrial'no-innovatsionnogo formirovniya obshchestva [State financial development institutions in addressing issues of industrial-innovative formation of society]. Almaty: Finances and credits(10), 11-16. 